\title{
Association and Division Membership among Small College Librarians
}

\section{Peter McCracken}

This study explores ALA membership among directors at small liberal arts colleges. Results show that directors at the smallest colleges are much less likely to be members of ALA and ACRL than their colleagues at larger colleges are. The study investigates trends based on the director's level of completed education, the director's tenure at her or his institution, and the relative size of the institutions. The discussion questions why directors at smaller colleges are less likely to be members of ALA and ACRL and examines how those associations might expand their services among these individuals.

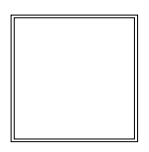

rofessional associations provide librarians with an array of membership choices. Although ALA and its divisions, such as ACRL, Library Administration and Management Association (LAMA), and Library and Information Technology Association (LITA); state associations; the Special Libraries Association (SLA); and others all offer a variety of networking, educational, publishing, and conference roles, they also all demand ever-increasing membership fees. Given the rising cost of association membership, how do librarians decide where and how to spend their membership money? How important is association membership to librarians and library directors? Among library directors at America's small colleges, how many are members of their primary organizations for advocacy and professional interaction? Perhaps information about who is-and who is not-a member of ALA, ACRL, and other associations can help each of these associations identify gaps in their membership and guide themselves to better serve more individuals and institutions.

This research attempts to determine ALA membership among a defined group of individuals. By starting with a group and then analyzing its membership characteristics, one can better understand the extent of ALA membership within the profession than one can from a self-selecting survey, in which a subject's membership status may affect his or her decision to respond to the survey. Baccalaureate I institutions comprise many of the nation's finest small liberal arts colleges, and an exploration of directors within this group offers an analysis of library directors in small colleges in America today.

An exploration of ALA membership rolls shows in which divisions and roundtables most Baccalaureate I college librarians hold membership and how many librarians are not members of ALA

Peter McCracken is a Reference Librarian in the Joyner Library at East Carolina University. From August 1999, McCracken will be a Reference and Instructional Librarian in Odegaard Undergraduate Library at the University of Washington; e-mail: mccrackenp@mail.ecu.edu. 
or ACRL, their primary professional associations. Not surprisingly, not all small college library directors are members of ALA and its related associations. About 25 percent of the college librarians in this study are not members of ALA, and 7 percent are members of ALA, but not ACRL. ${ }^{1}$ Among librarians in this study who are members of ALA and at least one division, just one college librarian is not a member of ACRL, even though this librarian directs a renowned library at one of the nation's best small colleges. On average, librarians who are members of ALA and at least one division direct significantly larger libraries than do those who are not members of ALA or one of its associations.

\section{Literature Review}

Articles about associations and their importance to librarians in general, much less to college library directors, are rare. The fall 1997 issue of Library Trends addressed many different aspects of the subject, and Sue Kamm's article questioned how librarians decide whether to join professional associations. ${ }^{2}$ In a survey distributed through listservs, Kamm found that eight of the 116 respondents to her survey claimed not to be members of a library association, primarily because of the cost of dues. She explored why just 7 percent of her respondents are not members of a library association and then provided several possibilities for why the level of participation appears so high.

\section{On average, librarians who are members of ALA and at least one division direct significantly larger libraries than do those who are not members of ALA or one of its associations.}

In the same issue, Barbara J. Glendenning and James C. Gordon discussed the role that professional associations play in promoting leadership among academic librarians and, by extension, the role that leadership plays for academic librarians. ${ }^{3}$ They studied litera- ture on leadership in libraries and provided a broad framework for the interaction of professional associations within library leadership, but they did not look at the extent of ALA membership among library directors.

In a 1991 survey of Oklahoma academic librarians, W. Michael Havener and Philip Worrell found that 55.7 percent of the college librarians responding to their survey were members of ALA, and 87.3 percent were members of one or more associations, usually the state association. Surprisingly, their results are not far from the self-selected results in Kamm's listserv survey. ${ }^{4}$

\section{Methodology}

The author used the Carnegie Foundation's Classification of Institutions of Higher Education as a sampling frame and selected every second college included in the Baccalaureate (Liberal Arts) Colleges I listing. ${ }^{5}$ The primary goal of the research was to study professional association membership among college librarians and the size of their libraries and parent institutions. Institutions with acting directors, rotating deans of the library, or libraries that served more than one discrete institution were replaced with institutions not under such limitations.

The 1997-1998 ALA Membership Directory provided ALA, division, and roundtable membership information. ${ }^{6}$ This study explored membership in roundtables as well as ALA divisions because both require a fee in addition to standard ALA membership, although the membership fee for roundtables is less, on average, than it is for associations. For renewals by professionals, ALA membership now costs $\$ 100$. ALA division memberships range from $\$ 35$ to $\$ 50$ each. The roundtables in which subjects of this study are members cost between $\$ 10$ and $\$ 15$ each. $^{7}$ Moreover, roundtables provide many valuable services similar to associations. In the case of the Government Documents Round Table (GODORT), an academic librarian in Kamm's article reported that "for my 
area of specialization, ALA GODORT is the organization to belong to." 8

Biographical information on subjects in this research came from Who's Who, college catalogs, personal Web pages, and various other sources. Statistical information on libraries came from the 1996 preliminary Integrated Postsecondary Education Data System (IPEDS) database, compiled by the U.S. Department of Education's National Center for Education Statistics; and college enrollment numbers were drawn from Barron's Profiles of American Colleges, 1998 edition. ${ }^{9}$

After collecting and compiling the available information, the author emailed all directors for whom e-mail addresses could be found to request confirmation or correction of the gathered information. The e-mail survey to 89 percent of the subjects produced a 79 percent response rate, and nearly all information was accurate; a surface mail confirmation attempt seemed unnecessary.

\section{Results}

Despite the resources and opportunities ALA and ACRL provide to librarians, such as publications, networking resources, and leadership experience, many college librarians do not seem to find ALA membership a requirement for their position. In responding to the request for corrections, a number of librarians wrote that high ALA dues had forced them to let their memberships lapse. However, others found enough value in the membership of professional associations to be members of four, five, and even six associations. For these directors, association membership offers returns greater than the cost of membership. One library director, listed in the ALA membership directory as being a member of multiple associations, indicated that, in fact, the director has a personal membership in just a few associations, while the director's library pays for several other memberships and then receives those associations' journals.

Among the subjects in this study, only one is a member of more roundtables than divisions. This individual is a member of two divisions and three roundtables. Generally, however, one roundtable (or in one case, two) is added to membership in between one and five divisions. The nine members who comprise the dozen roundtable memberships also hold twenty-five memberships in divisions. Given the much greater number of memberships in divisions than in roundtables, library directors clearly place more importance on division membership than on roundtable membership, despite the significantly greater cost of the former.

\section{Moreover, length of tenure as director does not seem to affect ALA membership}

A director's level of educational attainment does not affect his or her level of membership in ALA. As shown in table 1 , of sixteen library directors who are known to hold Ph.D.s, five are members of ALA and ACRL, and five are not members of ALA at all. Division membership for the remaining six individuals varies from no divisions to five divisions. Among thirty-four library directors holding an MLS only, ten are members of ALA and ACRL, and one is a member of ALA and LAMA, but not ACRL. Nine are not members of ALA at all. Such divisions reflect the overall collection of small college library directors: of eighty-two directors for whom information could be obtained, ${ }^{10}$ twenty-one are members of ALA and one other division (ACRL in all but one instance) and twenty-one are not members of ALA at all. Eighteen are members of ALA, ACRL, and one other division, most often LAMA. Eleven are members of ALA and three divisions, one is a member of ALA and four divisions or roundtables, three are members of ALA and five divisions or roundtables, and two are members of ALA and an impressive six divisions or roundtables. One college library director is also a life member of ALA.

Moreover, length of tenure as director does not seem to affect ALA membership 
(see table 2). Of two directors who have held their positions for more than thirty years, one is a member of three divisions or roundtables, and one is a member of ALA, but no divisions or roundtables. Among those holding their position for twenty-six to thirty years, two have two divisional memberships and two have no membership in ALA at all. Among those who have been directors for ten years or less, twenty-nine hold membership in ALA and ACRL, including nineteen who hold membership in more divisions. Three people who have held their position for ten years or less are members just of ALA, and eight are not members at all.

Table 3 shows that librarians who are members of ALA, but not ACRL or any other ALA associations, run much smaller libraries, with fewer books, dollars, students, or staff, than do other librarians in the study. On the other hand, just over one quarter of the group (twenty-two of eighty-three) are members of ALA and one association, and twenty-one are not members of ALA at all. Those in the latter group have just 72 percent of the budget of the former group and 73 percent of the volume of books of the former group. The latter group has 83 percent of the students in the former group, so in the end the latter group has fewer books and dollars per student than the former group does.

Among all the divisions and roundtables of which directors are members, an overwhelming majority are members of ACRL. Table 4 shows that LAMA, not surprisingly, is second with twentyfour directors as members, RUSA follows with eleven member-directors, and ALCTS and LITA both have nine members within this study group. As previously mentioned, roundtables are not a major source of membership for library directors. Just twelve of 122 memberships are in roundtables. The Intellectual Freedom and Social Responsibilities Round Tables are the most popular, with each having four library directors as members. Perhaps surprisingly, the round table most similar to a division in its professional ser- 


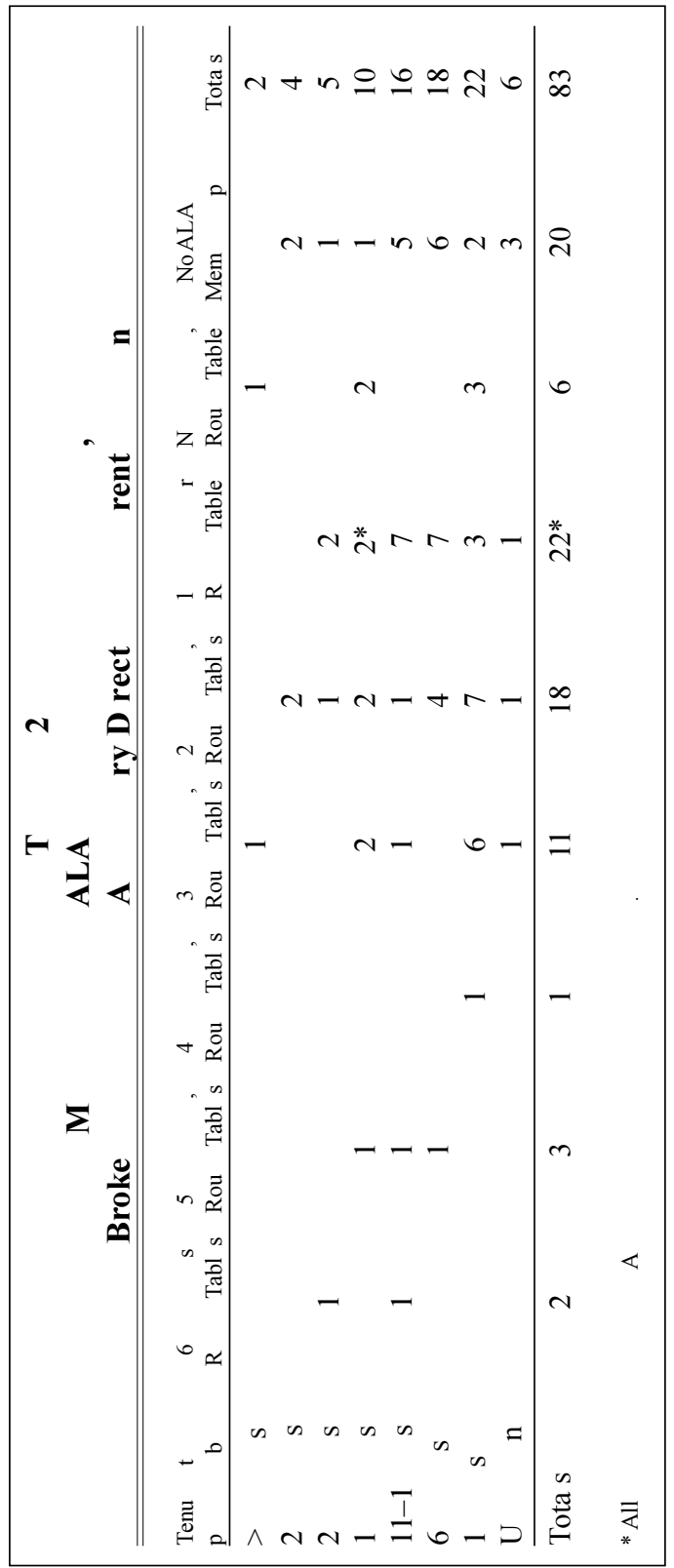

surprising that so many directors do not have their own memberships in ALA, their primary professional organization and the major source of publishing and intellectual exchange for academic librarians. Although ALA membership is considered expensive by many, the most recent dues increase was approved by 64 percent of votes cast. ALA officers argued strongly for the increase and favorably compared ALA's dues to those of other professional associations. Of course, those who already feel that association membership is too expensive, and are not members, did not have the opportunity to vote.

This study confirms the existence of a relationship between a library director's ALA and division membership and the library's size of budget or collection. However, it does not show how the two are related. For example, a library's limited budget may preclude a director from maintaining association membership. Directors at larger college libraries may feel a greater need to "keep up" with professional developments through association membership than their colleagues at smaller institutions do. Nevertheless, the relationship is significant, and may merit further study. Library directors who are members of more associations direct libraries with larger budgets, more books, and more staff than do directors who are not members of just ALA or ALA and one association. Perhaps

vice, GODORT, can count only one library director among its members.

\section{Discussion}

The results of this research suggest that many librarians are ambivalent about the value of association membership. Just less than one quarter of these library directors are not ALA members at all. It seems directors with more than two association memberships are more involved in networking with others and sharing their ideas and opinions. Perhaps through their interaction with other association members they gain knowledge on how to increase funding and support for their library, or how to better promote their library on their campus. 


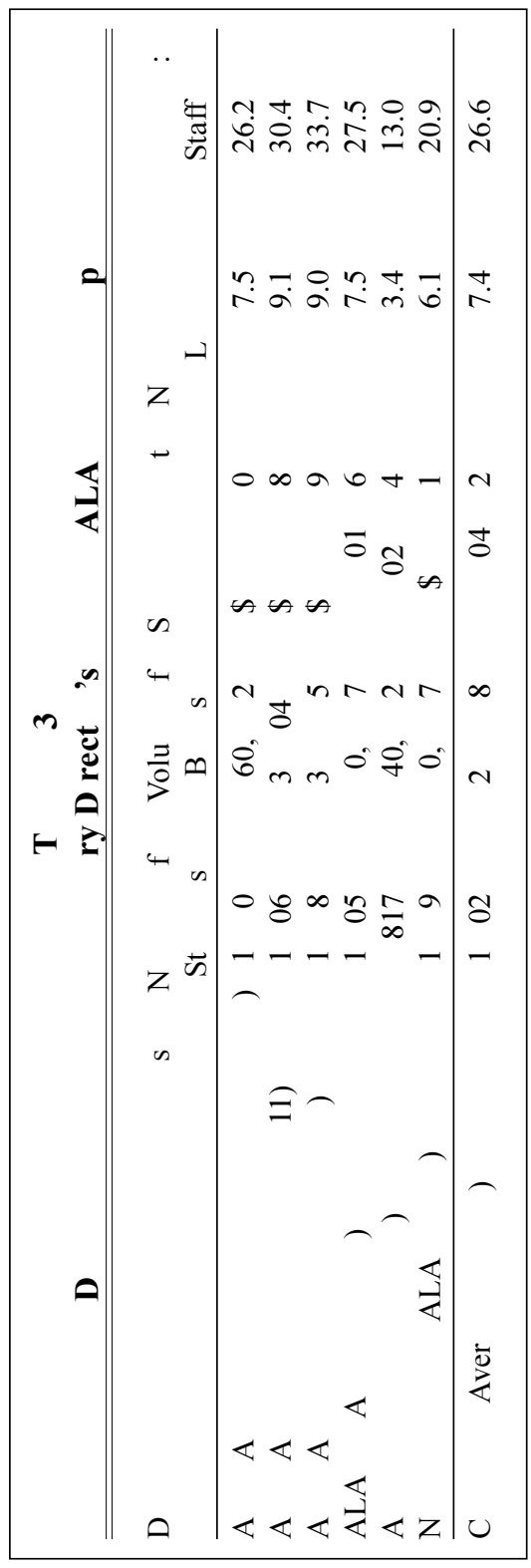

It is possible that librarians at colleges with the fewest students choose not to spend their money or their institution's money on ALA membership. Of the ten smallest schools by number of students, seven library directors are not members of ALA, and two are members of ALA, but not ACRL. But money is available: the large group of individuals who are not members of ALA have budgets more than half again as large as those who are members of ALA, but not ACRL. Among the ten largest schools by student enrollment, just three library directors are not members of ALA. Two of the other seven are members of ALA and ACRL alone; the other five are members of at least one division (in four cases, LAMA) in addition to ACRL.

Among the larger half of these schools, just five library directors are not members of ALA, and one other is a member of ALA, but not ACRL or LAMA. ${ }^{11}$ Among the smaller half, sixteen directors are not members of ALA, and four are members of ALA, but not ACRL. Clearly, librarians at smaller schools are less likely to sustain membership in ALA. Perhaps ALA and (especially) ACRL need to look at the directors of these smaller institutions to try to understand why they do not value membership as much as librarians at larger liberal arts colleges do. Both associations have something to offer the smaller liberal arts colleges; at least a few of these directors are willing to continue paying for their membership. But more of them are not, and perhaps ALA and ACRL should explore improving the services they provide to the nation's smallest liberal arts colleges.

To increase membership among small college directors, ALA and ACRL could consider offering membership dues on a graduated scale based on personal income.

Although many small college librarians are not members of ALA and/or ACRL, many others are, and, in some cases, maintain as many as six division or roundtable memberships. Those who are members of ALA and its divisions are impressively active: among the fiftyseven members of ALA and at least one division, twenty-one are listed in the 1997-1998 Handbook of Organization as division officers or committee members. None of those listed in the Handbook work with roundtables; instead, all work is done at the association or division level. 


\begin{tabular}{|cccc|}
\hline \multicolumn{5}{|c|}{$\begin{array}{r}\text { TABLE 4 } \\
\text { Membership in ALA Associations and Roundtables } \\
\text { among Library Directors at Small Colleges }\end{array}$} \\
\hline \hline Divisions & No. of Members & Round Tables & No. of Members \\
\hline ACRL & 56 & IFRT & 4 \\
LAMA & 24 & SRRT & 4 \\
RUSA & 11 & GODORT & 1 \\
ALCTS & 9 & IRRT & 1 \\
LITA & 9 & LIRT & 1 \\
YALSA & 1 & LHRT & 1 \\
\hline
\end{tabular}

consider offering membership dues on a graduated scale based on personal income. However, because the directors at many small colleges probably have greater incomes than the average ALA or ACRL member,

Fully 37 percent of library directors who are ALA and division members are active in the leadership of those divisions. Directors at schools with larger student bodies are much more active than are directors at schools with smaller student bodies; only one director among the smallest twenty-five schools on this list is mentioned in the Handbook of Organization. Half the directors of the thirty largest schools are mentioned in the Handbook of Organization as being involved in the guidance of ALA or its divisions.

\section{Conclusion}

Library directors at the largest small colleges in America are clearly more involved in ALA and division memberships and activities than their colleagues at smaller colleges. Establishing correlations between library directors' association with ALA and its divisions and the size of their library, institution, or budget will be difficult without interviews and indepth research. Nevertheless, it is clear that directors at larger institutions are more involved in ALA and its divisions. Perhaps this association, and its related interaction with other library directors, encourages better use of limited resources and supports further advancement of both the director's library and her or his career at larger schools.

To increase membership among small college directors, ALA and ACRL could that might actually decrease membership among small college directors. Library association membership is not extraordinarily expensive and is within reach of many librarians, regardless of their position or the size of their library. To suggest that directors, who probably have the largest salaries of any professional in their library, do not join ALA or ACRL because of cost makes little sense. The answer seems, then, that if ALA and ACRL want to attract and retain these directors as members, they must provide services better designed to meet the needs of small college librarians.

For directors who are not ALA members, simply paying $\$ 150$ annually for membership in ALA and two divisions will not guarantee a dramatic increase in the library's budget. Further research is needed to determine why directors at smaller colleges are not members of ALA or ACRL as often as their counterparts at larger institutions. The interaction and the opportunities provided by ALA, ACRL, and other divisions may provide library directors with the resources they need to improve and expand their collections and the services they provide to their patrons. Research that shows the nonmonetary value of association membership could help isolate these disparities in membership, and help ALA and ACRL better serve these underrepresented communities.

\section{Notes}

1. Membership in ALA is a prerequisite for membership in ALA's constituent associations, 
such as ACRL, LAMA, and LITA. Exploration into support for ALA, versus support for its constituent associations alone, might show that ALA has many members who value their ALA membership only for membership in the constituent associations.

2. Sue Kamm, "To Join or Not to Join: How Librarians Make Membership Decisions about Their Associations," Library Trends 46 (fall 1997): 295-306.

3. Barbara J. Glendenning and James C. Gordon, "Professional Associations: Promoting Leadership in a Career," Library Trends 46 (fall 1997): 258-77.

4. W. Michael Havener and Philip Worrell, "Environmental Factors in Professional Development Activities: Does Type of Academic Library Affiliation Make a Difference?" Library E Information Science Research 16 (summer 1994): 219-39. Their definition of college librarians consisted of academic librarians at all institutions classed as Liberal Arts Colleges I and II and Comprehensive Colleges and Universities I and II institutions from the 1987 Carnegie classification (Carnegie Foundation for the Advancement of Teaching, A Classification of Institutions of Higher Education, 1987 Edition [Princeton, N.J.: Carnegie Foundation, 1987]). These terms were changed to "Baccalaureate (Liberal Arts) Colleges" and "Master's (Comprehensive) Colleges and Universities," respectively, in the 1994 edition.

5. Carnegie Foundation for the Advancement of Teaching, A Classification of Institutions of Higher Education, 1994 Edition (Princeton, N.J.: Carnegie Foundation, 1994).

6. ALA, ALA Membership Directory, 1997-1998 (Chicago: ALA, 1997).

7. ALA, ALA Handbook of Organization, 1997-98 (Chicago: ALA, 1997), vii-viii.

8. Kamm, To Join or Not to Join, 303.

9. National Center for Education Statistics, Preliminary 1996 Academic Library Data [subset of Integrated Postsecondary Education Data System] (Washington, D.C.: U.S. Department of Education, 1997). Available online at: http: / / nces.ed.gov/Ipeds/aclib96.html; Barron's Profiles of American Colleges, 22nd ed. (Hauppauge, N.Y.: Barron's, 1997).

10. Educational data on one individual could not be found.

11. Measurement by student enrollment, $n=42$. The mean average enrollment for all schools is 1,502 students. The average for the smaller half is 880 students, and the average for the larger half is 2,109 . The range is from 223 to 5,980 students. 